\title{
Status Hukum Ketetapan MPR/S Setelah Perubahan UUD 1945
}

\author{
R. Nazriyah
}

\begin{abstract}
The decision of Legislative No.//Legislative Assemble/2003, demonstrates that the juridical issue relates to the obviousness of the substance and legal status of the substance and the legal status of the GeneralAssembly (Temporary) has not been removed, because there some decisions which still exist. To solve the problems, the altemative solution is to convert the important substance which contains the decision of the Legislative Assembly (Temporary) into Law.
\end{abstract}

\section{Pendahuluan}

Pada Sidang Tahunan MPR Keempat tahun 2002 diputuskan untuk mengkaji ulang materi muatan dan keberadaan Ketetapan MPR/ $S$ sebagai sumber hukum di Indonesia, untuk diambil putusan pada sidang MPR tahun 2003. Tugas ini diberikan sebagai konsekuensi berubahnya kedudukan, susunan, tugas dan wewenang MPR melalui Perubahan Ketiga UU'D 1945. Perubahan tersebut telah membawa dampak tidak hanya pada kelembagaan MPR tetapi juga struktur kelembagaan negara yang ada, serta aturan-aturan hukum yang berlaku di negara Republik Indonesia.

Latar belakang munculnya penugasan kepada MPR untuk melakukan peninjauan terhadap materi dan status hukum Ketetapan

MPR/S tersebut, diawali dengan adanya pikiran sederhana Panitia Ad Hoc (PAH) I BP MPR yaitu : setelah diubahnya UUD 1945, MPR tidak lagi berwenang membuat produk hukum yang bersifat mengatur (regeling). Disamping itu, banyak materi muatan Ketetapan MPR/S yang tidak sesuai dengan apa yang seharusnya menjadi materi muatan Ketetapan MPR. Misalnya, Ketetapan tentang Pengangkatan Presiden Seumur Hidup; Ketetapan tentang Referendum; Tata Cara Pemilihan Presiden dan Wakil Presiden; Mekanisme Pemberhentian Presiden dan atau Wakil Presiden dan seterusnya. Sehingga di bawah undang-undang dasar hanya ada undang-undang dan tidak ada lagi ketetapan MPR. ${ }^{1}$

'Kompas, 1 Agustus 2003. Ketentuan Pasal 1 Aturan Tambahan dirumuskan sebagai tindak lanjutadanya perubahan Undang-Undang Dasar 1945, khususnya yang terkait dengan perubahan kedudukan dan wewenang MPR sehingga perlu ada peninjauan terhadap materi dan status hukum Ketetapan MPRS dan Ketetapan MPR. Lihat MPR RI. 2003. Panduan Dalam Memasyarakatkan Undang-Undang Dasar Negara Republik Indonesia Tahun 1945, Latar Belakang, Proses dan Hasil Perubahan Undang-Undang DasarNegara 
Untuk itu, Pasal | Aturan Tambahan UUD 1945 hasil perubahan keempat mengamanatkan, "Majelis Permusyawaratan Rakyat ditugasi untuk melakukan peninjauan terhadap materi dan status hukum Ketetapan MPR/S untuk diambil putusan pada Sidang MPR tahun 2003". Pekerjaan untuk melakukan penelitian terhadap 139 Tap MPR/ $S$ yang diterbitkan dari periode 1960 sampai 2002 tersebut diserahkan kepada panitia Ad Hoc BP MPR dalam Sidang Tahunan 2003.

Sebelum UUD 1945 diubah, MPR merupakan suatu lembaga tertinggi negara yang melakukan "amanat" kedaulatan rakyat sebagaimana tercantum dalam Pasal 3 ayat (1) UUD 1945. MPR mempunyai tugas dan wewenang menetapkan dan mengubah UUD, menetapkan garis-garis besar haluan negara (GBHN), serta memilih Presiden dan Wakil Presiden. Sebagai "pengemban kedaulatan rakyat" MPR mengatur dirinya melalui keputusan dan ketetapan. ${ }^{2}$

Setelah terjadi perubahan terhadap UUD 1945 , kedudukan, tugas, dan wewenang MPR mengalami perubahan. MPR bukan lagi sebagai lembaga tertinggi negara, namun sejajar dengan lembaga-lembaga tinggi negara lainnya. Wewenang MPR mengalami pengurangan, MPR tidak lagi berwenang memilih Presiden dan Wakil Presiden tetapi hanya melantik Presiden dan/atau Wakil Presiden pilihan rakyat secara langsung. Disamping itu, MPR hanya dapat memberhentikan Presiden dan/atau Wakil Presiden dalam masa jabatannya menurut UUD. ${ }^{3}$ MPR tidak lagi berwenang menetapkan Garis-garis Besar Haluan Negara (GBHN), tetapi hanya berwenang mengubah dan menetapkan UUD.

Sejak dibentuknya MPRS melalui Dekrit Presiden Republik Indonesia Pada tanggal 5 Juli 1959, sejarah ketatanegaraan Republik Indonesia khususnya kehidupan struktur politik seperti MPR mulai berkembang. MPR sebagai pengemban kedaulatan rakyat bersidang sedikitnya sekali dalam lima tahun. Dalam setiap sidang MPR menghasilkan Ketetapan atau Keputusan sebagai garis-garis besar daripada haluan negara yang akan dilaksanakan oleh Presiden sebagai mandataris MPR. Dalam sejarah ketatanegaraan di Indonesia, bentuk Ketetapan MPR mulai dikenal sejak dikeluarkannya Ketetapan MPRS No. IMPRS/ 1960 tentang Manifesto Politik RI Sebagai Garisgaris Besar daripada Haluan Negara.

MPR(S), mengeluarkan Produk hukum bernama Ketetapan MPR(S) sebagai konsekuensi dari wewenang yang dimilikinya berdasarkan Pasal 3 UUD 1945 yang berbunyi:" Majelis Permusyawaratan Rakyat menetapkan Undang-Undang Dasar dan. Garis-garis Besar daripada Haluan Negara". Karena "menetapkan" maka bentuknya diberi nama Ketetapan. ${ }^{4}$

Pada tahun 1966, MPRS menerbitkan Ketetapan MPRS No. XX tahun 1966 tentang

Republik Indonesia Tahun 1945. Sekretariat Jenderal MPR RI. Jakarta., hlm. 237.

2Penegasan ini dapat disimak dalam Ketetapan No. I/MPR/1973 Tentang Peratuan Tata - Tertib MPRRl (Pasal 102) dan Ketetapan MPR - RI No. II/MPR/1999 Tentang Tata - Tertib MPR - Ri.

${ }^{3}$ Pemberhentian Presiden danjatau Wakil Presiden dilakukan setelah prosedur didalam ketentuan Pasal 7 A dan 7B UUD 1945 dilalui.

${ }^{4 B}$ agir Manan. 1992. Dasar-Dasar Perundang-Undangan Indonesia. Ind-Hill. CO. Jakarta., him. 32. 
Memorandum DPR-GR mengenai Sumber Tertib Hukum RI dan Tata Urutan PerundangUndangan $\mathrm{Rl}$, yang menempatkan Ketetapan MPRS sebagai salah satu sumber hukum dalam tata urutan tersebut. Berarti, sejak tahun 1966 keberadaan Ketetapan MPRS sebagai sumber hukum telah diakui dalam sistem hukum Indonesia.

Setelah dilakukan berbagai kajian dan evaluasi terhadap tata urutan peraturan perundang-undangan sebagaimana diatur dalam Ketetapan MPRS No. XX/MPRS/1966, pada tahun 2000 MPR kembali mengeluarkan Ketetapan MPR No. III/MPR/2000 tentang Sumber Hukum dan Tata Urutan Peraturan Perundang-undangan. Melalui Ketetapan MPR No. III/MPR/2000 beberapa kekurangan materi Ketetapan MPRS No. XX/MPR/1966 dikoreksi dan ditambahkan, yakni menghapuskan sumber hukum setingkat Instruksi Presiden, Keputusan Menteri dan seterusnya ke bawah. Adapun penambahannya adalah dimasukkannya Peraturan Daerah dalam tata urutan yang paling bawah dalam hierarki peraturan perundang-undangan. Melalui Ketetapan MPR No. III/MPR/2000 keberadaan Ketetapan MPRS No. XX/MPRS/1966 dicabut dan dinyatakan tidak berlaku lagi. Sehingga sumber acuan yang dipakai untuk melihat tata urutan peraturan perundang-undangan dalam sistem hukum nasional adalah Ketetapan MPR No. Ill/MPR/2000.5
Hasil pengkajian sementara terhadap materi Ketetapan MPRS maupun Ketetapan MPR menunjukkan tidak semua Ketetapan MPR/S yang selama ini ada dapat dikatakan sepenuhnya mengacu pada tiga tugas dan wewenang MPR menurut Undang-Undang Dasar 1945, melainkan lebih banyak mendasarkan diri pada kedudukannya, dengan segala interpretasinya. ${ }^{6}$

Mengenai status hukum Ketetapan MPR tersebut banyak kalangan yang berbeda pendapat, ada yang berpandangan bahwa setelah amandemen UUD 1945 seluruh Ketetapan MPR/S tidak berlaku karena MPR bukan lagi sebagai lembaga tertinggi negara yang bisa memerintahkan Dewan Perwakilan Rakyat (DPR) maupun Presiden. Pendapat lain yang lebih demokratis mengatakan bahwa, Ketetapan MPR yang ada sejak tahun 1960 perlu dipilah-pilah berdasarkan kepentingannya. Ketetapan MPRS dan MPR yang materi muatannya sangat penting dan perlu ditetapkan sebagai norma hukum, ditindaklanjuti untuk dituangkan dalam undang-undang atau undang-undang dasar.

Dalam perkembangannya, anggota $\mathrm{PAH}$ II MPR dengan bantuan pakar perguruan tinggi bersepakat membuat satu rancangan Ketetapan MPR untuk menuntaskan masalah status hukum 139 Tap MPRS/MPR tersebut. Namun, kesepakatan itu telah menimbulkan perbedaan pandangan dikaiangan pemimpin

${ }^{5}$ Ketetapan MPR No. Ill/MPR/2000 sudah tidak berlaku lagi, sebab undang-undang yang diperintahkan oleh Tap. MPR No. IMPR/2003 sudah terbentuk, yaitu UU No. 10 Tahun 2004 tentang Pembentukan Peraturan Perundang-undangan.

${ }^{6}$ Misalnya, pada masa Orde Lama pernah dikeluarkan TAP MPRS No. III/MPRS/1963 yang mengangkat Presiden Soekarno sebagai Presiden seumur hidup. Kemudian pada masa Orde Baru, dikeluarkan TAP MPR yang memberi kekuasaan tidak terbatas kepada Presiden demi pembangunan (Lihat TAP MPR No. V/MPR/ 1998). Atas dasar kekuasaan tak terbatas yang dimilikinya, MPR menetapkan berbagai ketetapan di luar yang ditentukan dalam UUD seperti Ketetapan tentang Pemilihan Umum. 
PAH I dan PAH II dalam melihat masalah kewenangan MPR membuat Tap MPR, apakah MPR berwenang membuat ketetapan setelah perubahan UUD 1945. Jika PAH I BP MPR menganggap MPR tidak lagi berwenang mengeluarkan ketetapan-ketetapan, PAH II justru membuat rantap yang akan dibawa ke Sidang Tahunan MPR 2003.

Rantap tersebut adalah Rantap MPR tentang Peninjauan terhadap Materi dan Status Hukum Ketetapan MPRS dan MPR Tahun 1960 sampai dengan Tahun 2002. Rantap tersebut diistilahkan dengan "rantap sapu jagad". Artinya cukup dengan mengeluarkan satu ketetapan, 'seolah-olah' selesailah persoalan status hukum ke 139 Tap MPRS/MPR tersebut.

Melalui Sidang Tahunan MPR tahun 2003 sebagai amanat konstitusi, telah diambil keputusan oleh MPR berkaitan dengan materi dan status hukum Ketetapan MPR/S sebagaimana tertuang dalam Ketetapan MPR R! No. 1/MPR/2003 tentang Peninjauan Terhadap Materi dan Status Hukum Ketetapan MPRS dan Ketetapan MPR RI Tahun 1960 Sampai Dengan Tahun 2002.

Melalui. Ketetapan MPR No. I/MPR/2003 tersebut, dapat kita ketahui bahwa persoalan yuridis yang berkaitan dengan kejelasan materi dan status hukum Ketetapan MPR/S ternyata belum juga dapat dituntaskan (dihapuskan), karena hanya sebagian kecil saja yang dicabut (dinyatakan tidak berlaku), sebagian lagi masih berlaku sampai dengan terbentuknya pemerintahan hasil Pemilu 2004, sebagian lagi dinyatakan berlaku sampai dengan terbentuknya undang-undang, dan sebagain lagi masih dipertahankan dalam bentuk Ketetapan MPR/S.

Mengacu kepada uraian di atas, maka masalah yang dapat dirumuskan adalah (1) Bagaimanakah kedudukan Ketetapan MPRS dan Ketetapan. MPR setelah perubahan UndangUndang Dasar 1945 dalam hierarki peraturan perundang-undangan? (2) Bagaimana status hukum Ketetapan MPRS dan Ketetapan MPR yang masih dinyatakan berlaku di masa yang akan datang?

\section{Konsepsi Negara Hukum}

Biasanya kedaulatan rakyat dikaitkan dengan demokrasi, sehingga apa yang diartikan dengan demokrasi sangat erat hubungannya dengan pengertian kedaulatan rakyat. Ajaran kedaulatan rakyat bermula dari Jean Bodin. Menurut dia, kedaulatan berarti kekuasaan mutlak tertinggi, tidak dapat dibagi atau dialihkan, dan bersifat langgeng. ${ }^{7}$ Sumber kekuasaan itu hanya satu yaitu sang raja, jadi pengertian kedaulatan yang diuraikan dan dikembangkan oleh Bodin adalah untuk memberi dasar hukum yang kuat bagi kekuasaan raja. Kemudian Jean Jacques Rousseau menempatkan kekuasaan tertinggi itu pada rakyat sehingga lahirlah pengertian kedaulatan rakyat. Konsepsi Rousseau mengenai kedaulatan rakyat mengajarkan bahwa penguasa adalah rakyat sendiri, pemerintahan oleh rakyat, dari rakyat, dan untuk rakyat. ${ }^{8}$

7 J.J. von Schmid. 1952. Grote Denkers over Staat en Recht. De erven F. Bohn NV. Haarlem. 3e druk. HIm. 117-119. Dalam A.S.S. Tambunan. 1991. MPR Perkembangan dan Pertumbuhannya Suatu Pengamatan dan Analisis, Cetakan Pertama. Muliasari. Jakarta. HIm. 18.

${ }^{8}$ ibid. 
Dalam hubungan ini, meminjam istilah yang digunakan oleh Frans Magnis Suseno mengenai kedaulatan rakyat, bahwa satu-satunya legitimasi dasar kekuasaan yang sah adalah legitimasi demokratis. Tidak ada orang atau kelompok orang yang begitu saja berhak untuk memerintah orang lain. Wewenang untuk memerintah masyarakat harus berdasarkan penugasan dan persetujuan para warga masyarakat sendiri. ${ }^{9}$ Dalam konteks ini pula ungkapan "vox populi vox Der" bahwa "suara rakyat adalah suara Tuhan" memiliki dasar kebenaran.

Menurut Sri Soemantri, dengan masih menganut paham kedaulatan rakyat harus dicari suatu sistem yang sesuai untuk membicarakan masalah kenegaraan dan kemudian mengambil keputusan bagi negara yang memiliki jumlah rakyat warga negaranya sudah berjumlah besar seperti Indonesia. Adapun sistem yang dianut di negara Republik Indonesia ialah yang diatur dalam UUD 1945. ${ }^{10} \mathrm{Negara}$ Indonesia menganut asas atau sistem kedaulatan rakyat. Hal ini ditegaskan oleh Pasal 1 ayat (2) UUD 1945 yang menyatakan bahwa " kedaulatan adalah di tangan rakyat dan dilakukan sepenuhnya oleh Majelis Permusyawaratan rakyat". Dengan demikian, berdasarkan UUD 1945 kedaulatan rakyat itu telah diwakilkan kepada MPR sebagai pemegang kekuasaan negara tertinggi, maka dengan demikian di negara kita dianut ketentuan "kekuasaan negara yang tertinggi berada di tangan MPR" atau Supremacy of the People's Consultative Assembly. "Menurut sistem ketatanegaraan Indonesia yang berdasarkan UUD 1945 kedaulatan adalah di tangan rakyat, sudah merupakan realitas konstitusional.

Sedangkan konsep kedaulatan hukum yang merupakan reaksi atas prinsip ajaran kedaulatan negara berintikan bahwa, setiap tindakan negara harus didasarkan pada hukum atau harus dipertanggungjawabkan secara hukum.

Dalam perkembangannya, konsep negara hukum mengalami perumusan yang berbeda-beda. Pandangan Immanuel Kant yang bersifat liberal memberikan gambaran tentang negara hukum berfungsi sebagai penjaga malam, artinya tugas negara hanya menjaga saja hak-hak rakyat jangan diganggu atau dilanggar, mengenai kemakmuran rakyat negara tidak boleh campur tangan negara sebagai nachtwachker staat. ${ }^{12}$ Paham tersebut tidak dapat dipertahankan lagi, sehingga negara terpaksa campur tangan dalam urusan kepentingan rakyat menurut saluran hukum yang sudah ditentukan, sehingga lahirlah negara hukum formil atau disebut juga rechtsstaat klasik.

Adapun ciri-ciri rechtsstaat klasik menurut FJ. Stahl adalah sebagai berikut: (i) Hak-hak asasi manusia (HAM); (ii) Pemisahan atau pembagian kekuasaan untuk menjamin HAM; (iii) Pemerintahan berdasarkan peraturanperaturan (wetmatigheid van bestuur). ${ }^{13}$

${ }^{9}$ Frans Magnis Suseno. 1989. Etika Politik. Gramedia Pustaka Utama. Jakarta. HIm. 289.

${ }^{10}$ Sri Soemantri. 1987. Prosedur dan Sistem Perubahan Konstitusi. Cetakan Keempat. Alumni. Bandung . HIm. 158.

"Ismail Suny. 1987. Mekanisme demokrasi Pancasila. Aksara Baru. Jakarta. Hlm. 16

${ }^{12}$ Moh. Kusnardi dan Harmaily Ibrahim. 1980. Pengantar Tata Hukum Indonesia. Pusat Studi HTN dan Sinar Bakti. Jakarta. HIm. 156.

${ }^{13}$ Moh. Mahfud MD. 1993. Demokrasi dan Konstitusidi Indonesia. Liberty. Yogyakarta. HIm. 28. 
Konsepsi negara hukum juga identik dengan konsep rule of law yang berkembang di Anglo Saxon. Menurut A.V. Dicey, ${ }^{14}$ ciri-ciri rule of law adalah: (i) Supremasi of law, artinya yang mempunyai kekuasaan tertiggi dalam negara adalah hukum; (ii) Equality before the law, artinya kedudukan yang sama di depan hukum; (iii) Constitution based on individual right, yakni terjaminnya HAM oleh undangundang dan keputusan-keputusan pengadilan.

Di Indonesia mengenai teori negara hukum dapat ditelusuri dalam UUD 1945. Di dalam Penjelasan UUD 1945 pada bagian sistem pemerintahan negara, dinyatakan bahwa negara Republik Indonesia berdasarkan atas hukum (rechtsstaat) dan tidak berdasar kekuasaan belaka (machtstaat). Selanjutnya dalam UUD 1945 Perubahan ketiga, pernyataan dianutnya teori negara hukum secara eksplisit dituangkan dalam Batang Tubuh UUD 1945 yaitu Pasal 1 ayat (3) yang berbunyi: "Negara Indonesia adalah negara hukum".

Pada umumnya konstitusi menggambarkan seluruh sistem ketatanegaraan suatu negara, kumpulan yang mendasari dan mengatur atau mengarahkan pemerintahan baik yang bersifat legal, dalam arti peraturan-peraturan yang diakui dan diterapkan oleh pengadilan hukum dan yang bersifat non-legal atau ekstra-legal, yaitu berupa kebiasaan, persetujuan, adat atau konvensi yang tidak diakui oleh pengadilan sebagai hukum tetapi tidak kalah efektifnya dalam mengatur pemerintahan dibandingkan dengan apa yang secara baku disebut hukum. ${ }^{15}$

Untuk melengkapi perumusan pengertian konstitusi, Penjelasan umum UUD 1945 secara tegas menyatakan bahwa :

"Undang-Undang Dasar suatu negara ialah hanya sebagian dari hukumnya dasar negara itu. Undang-undang dasar ialah hukum dasar yang tertulis sedang disampingnya undang-undang dasar itu berlaku juga hukum dasaryang tidak tertulis, ialah aturan-aturan dasar yang timbul dan terpelihara dalam praktek penyelenggaraan negara meskipun tidak tertulis".

Sementara itu, mengenai materi yang harus menjadi muatan konstitusi, menurut Sri Soemantri, ${ }^{16}$ dengan mengutip J.G. Steenbeek pada umumnya berisi tiga hal pokok, yaitu:

1. Adanya jaminan terhadap hak-hak asasi manusia dan warga negara;

2. Susunan ketatanegaraản yang bersifat fundamental;

3. Pembagian dan pembatasan tugas ketatanegaraan yàng juga bersifat fundamental.

${ }^{14}$ A.V. Dicey. Introduction to the Study of the Conitution. HIm. 202 dan 203. Dalam Azhary. 1995. Negara Hukum Indonesia, Analisis Yuridis Normatif Tentang Unsur-unsurnya. UI Press. Jakarta. HIm. 20-21

${ }^{15}$ K.C. Wheare. 2003. Modern Constitutions. Penerjemah Muhammad Hardani. Konstitusi-Konstitusi Modern. Cetakan Pertama. Pustaka Eureka. Surabaya. HIm. 1

${ }^{16}$ Sri Soemanti. Op. cit. Hlm. 35. Beberapa Konstitusi modem berisi deklarasi tentang hak-hak rakyat, tujuantujuan politik, sumber dan tujuan pemerintah yang terkait dengan studi tentang masalah konstitusional. Ada juga negara yang Konstitusinya tidakmengandung paham konstitușional. Contoh Konstitusi yang berisi materi yang pada dasarnya tidak mempunyai watak konstitusional adalah ketetapan yang dituangkan dalam Konstitusi Swiss (Pasal 25 bis) pada 1893, yang melarang tukang daging melakukan penyembelihan binatang kecuali kalau binatang itu telah dipinsankan terlebih dahulu. Lihat K.C. Wheare. 2003. Konstitusi ... op. cit. Him. 50. 
Berdasarkan uraian di atas, jika kita cermati ajaran sistem konstitusi (constitutionalism) ini, maka hampir mustahil kita menjumpai suatu negara di dunia saat ini yang tidak menerapkan sistem konstitusi. ${ }^{17}$ Oleh karena itu negara dan konstitusi tidak dapat dipisahkan satu dengan yang lain, sebab seperti dikemukakan oleh Henc van Maarseveen dan Ger van der Tang, konstitusi merupakan a birth certificate as a sight of adulthood and independence dari adanya suatu negara. ${ }^{18}$

\section{Peninjauan Terhadap Ketetapan MPR/S}

Semenjak tahun 1960 sampai dengan Sidang Umum Tahunan 2002, MPR telah mengeluarkan Ketetapan-ketetapan MPR(S) sebanyak 139 Ketetapan MPR(S). ${ }^{19}$ Banyaknya Ketetapan MPR(S) tersebut tidak terlepas dari luasnya wewenang yang dimiliki oleh MPR sebelum amandemen UUD 1945. Namun, Ketetapan-ketetapan MPR tersebut menunjukkan tidak semua Ketetapan MPR/S yang selama ini ada dapat dikatakan sepenuhnya mengacu pada tiga tugas dan wewenang MPR menurut Undang-Undang Dasar 1945, melainkan lebih banyak mendasarkan diri pada kedudukannya, dengan segala interpretasinya.

Sebenarnya keinginan untuk melakukan peninjauan terhadap materi dan status hukum Ketetapan MPR/S tidak diketahui secara jelas namun, apabila dilihat latar belakang munculnya rumusan tentang penugasan kepada MPR untuk meninjau materi dan status hukum Ketetapan MPR/S, keinginan tersebut diawali dengan adanya pikiran sederhana PanitiaAd Hoc (PAH) I BP MPR sebagimana dikemukakan di atas.

Untuk itu, Pasal I Aturan Tambahan UUD 1945 hasil perubahan keempat mengamanatkan kepada MPR untuk melakukan peninjauan terhadap seluruh Ketetapan MPR/S yang pernah diterbitkan. Demikian juga dalam konsideran "menimbang" huruf (b,c,dan d) ketetapan MPR No.I/MPR/2003 tentang Peninjauan terhadap Materi dan Status Hukum Ketetapan MPR(S) RI

${ }^{17}$ Esensi konstitusionalisme, minimal terdiri dari dua hal: Pertama,konsepsinegara hukum yang menyatakan bahwa secara universal kewibawaan hukum haruslah mengatasi kekuasaan pemerintah yang karenanya hukum harus mampu mengontrol dan mengendalikan politik; Kedua, konsepsi hak-hak sipil warga negara yang menggariskan adanya kebebasan warga negara di bahaw jaminan konstitusi sekaligus adanya pembatasan kekuasaan negara yang dasar legitimasinya hanya dapat diperoleh oleh konstitusi. (Soetandyo Wignjosoebroto. Dalam Moh. Mahfud MD. 1999. Amandemen Konstitusi Menuju Reformasi Tata Negara. Cetakan Pertama. Ull-Press. Yogyakarta. Him. 61)

${ }^{18}$ Sri Soemantri M. Fungsi Konstitusi Dalam Pembatasan Kekuasaan. Dikutip dari Jurnal Hukum. №. 6 Vol. 3 Tahun 1996. HIm. 4. Selanjutnya Sri Soemantri mengatakan, "bahwa saat berdirinya negara tidak selalu jatuh dalam waktu yang sama dengan terbentuknya konstitusi, ini tidak hanya dialami oleh Indonesia tapi juga dialami Bangsa Belanda, Bangsa Amerika Serikat dan Rakyat Republik Sosialis Uni Soviet. Jarak waktu berdirinya Negara Belanda dan ditetapkannya konstitusi kurang lebih 4 bulan, sedangkan Republik Soviet Federal Sosialis Rusia (sebelum bemama Sosialis Uni Soviet) jarak waktu itu kurang lebih 10 bulan. Untuk Amerika Serikat, jarak waktunya ternyata 11 tahun". (Pidato Pengukuhan Guru Besar pada FH UNPAD Bandung, tanggal 21 Pebruari 1987, yang berjudul “Undang-Undang Dasar dan Ketetapan Majelis Permusyawaratan Rakyat SebagaiProduk Majelis Permusyawaratan Rakyaf', him. 1.)

${ }^{19}$ Mohammad Fajul Falaakh.et. al. Laporan Akhir Kajjan tentang "Peninjauan terhadap Materi dan Status Hukum Ketetapan MPRS dan MPR Tahun 1960-2002.' Kerjasama Setjen MPR-RI dengan UGM. Yogyakarta. 2002. 
Tahun 1960 sampai dengan 2002, hanya menyatakan bahwa dengan adanya Perubahan UUD 1945 Negara Republik Indonesia telah menyebabkan terjadinya perubahan struktur kelembagaan negara yang berdampak pada perubahan kedudukan, fungsi, tugas, dan wewenang lembaga negara dan lembaga pemerintahan yang ada. Perubahan tersebut mempengaruhi aturan-aturan yang berlaku menurut UUD Negara Republik Indonesia Tahun 1945 dan mengakibatkan perlunya dilakukan peninjauan terhadap materi dan status hukum Ketetapan MPR(S).

Menurut Badan Pekerja MPR 2003, ${ }^{20}$ tugas "Meninjau materi dan status hukum ketetapan MPR/S yang diputuskan pada Sidang MPR tahun 2003" diartikan sebagai: 1) meninjau terhadap materi ketetapan MPR/ $S$; dan 2) menetapkan status hukum Ketetapan MPR/S. Namun hal ini menunjukkan ketidakjelasan tentang : a) makna meninjau Ketetapan MPR/S; b) meninjau materi yang terdapat dalam naskah Ketetapan MPR/S; c) meninjau status hukum ketetapan MPR/S. Istilah "meninjau" kemudian bermakna mempelajari kembali semua ketetapan MPR/S yang telah diterbitkan antara 1960-2002.

Pilihan yang tersedia untuk mewadahi peninjauan Ketetapan MPR/S adalah UUD, Ketetapan MPR atau UU. Ketetapan MPR masih merupakan pilihan konstitusional yang tersedia. Namun demikian, ada beberapa pihak yang mengatakan bahwa keberadaan Ketetapan MPR/S yang berkembang sebagai konvensi ketatanegaraan hanya dapat ditiadakan jika berkembang konvensi yang sebaliknya.

Langkah apa yang hans dilakukan ketika menggunakan bentuk hukum yang akan dipilih: mencabut Ketetapan; memindahkan ke dalam undang-undang; membiarkan sebagai Ketetapan MPR/S; membuat model Ketetapan No. V/MPR/1973; dan melanjutkan amandemen.

Berdasarkan hasil peninjauan yang dilakukan oleh MPR dalam Sidang Tahunan 2003, terlihat bahwa MPR telah memilih keempat bentuk hukum sebagaimana dikemukakan di atas dan sebagian menggunakan model Ketetapan MPR No. V/MPR/1973, kecuali melanjutkan perubahan sebab, MPR tidak berkeinginan lagi melakukan perubahan terhadap Undang-Undang Dasar 1945. ${ }^{21}$

Hasil peninjauan yang dilakukan oleh MPR melalui Ketetapan MPR No. IMPR/2003 tentang Peninjauan Terhadap Materi dan Status Hukum Ketetapan MPRS dan Ketetapan MPR RI Tahun 1960 - 2002, menggolongkan Ketetapan MPR/ $S$ ke dalam enam kelompok, yaitu:

(a) Tap. MPR/S yang dicabut dan dinyatakan tidak berlaku. Oleh karena materi muatan ketetapan-ketetapan MPR tersebut sudah

${ }^{20}$ Fajrul Falaakh. Et. al. Ibid. HIm. 10

2'Keinginan'MPR untuk tidak mengamandemen UUD 1945 harus mengalami kenyataan berbeda, karena mayoritas anggota Komisi Konstitusi menilai Perubahan I, II, III, dan IV UUD 1945 yang dihasilkan MPR sarat dengan masalah. Atas dasar itu, mereka bersepakat untukmenyempurnakannya secara maksimal, baik dalam hal sistematika, sinkronisasi, maupun perubahan substansi pasal-pasal. Sri Soemantri mengemukakan bahwa, pasal-pasal dalam Perubahan UUD 1945 banyak yang bertentangan satu dengan lain. Lihat Kompas, 23 Oktober 2003. Komisi Konstitusi telah menghasilkan dua naskah akademik yaitu, naskah kajian komprehensif Komisi Konstitusi tentang perubahan UUD 1945 dan naskah Perubahan UUD 1945 hasil Komisi Konstitusi. Jurnal Sidang MPRNo. 5. Edisi 27 september 2004. 
diintegrasikan ke dalam pasal-pasal UUD melalui perubahan UUD 1945, maka lebih tepat jika ketetapan tersebut dicabut.

(b) Ketetapan MPR/S yang dinyatakan tetap berlaku dengan ketentuan masing-masing sebagai berikut:

1 Tap. MPR/S No. XXV/MPRS/1966 tentang Pembubaran Partai Komunis Indonesia, Pemyataan Sebagai Organisasi Terlarang di Seluruh Wilayah Negara RI bagi Partai Komunis Indonesia dan Larangan Setiap Kegiatan untuk Menyebarkan atau Mengembangkan Faham atau Ajaran KomunisMarxismeLeninisme dinyatakan tetap berlaku dengan ketentuan seluruh ketentuan dalam Ketetapan MPRS-RI No. XXV/ MPRS/1966 ini, kedepan diberlakukan dengan berkeadilan dan menghormati hukum, prinsip demokrasi dan hak asasi manusia.

2 Tap. MPR No. XVIMPR/1998 tentang Politik Ekonomi dalam Rangka Demokrasi Ekonomi, dinyatakan tetap berlaku dengan ketentuan Pemerintah berkewajiban mendorong keberpihakan politik ekonomi yang lebih memberikan kesempatan dukungan dan pengembangan ekonomi, usaha kecil menengah, dan koperasi sebagai pilar ekonomi dalam membangkitkan terlaksananya pembangunan nasional dalam rangka demokrasi ekonomi sesuai hakikat Pasal 33 UUD RI 1945.

3 Ketetapan MPR No. V/MPR/1999 tentang Penentuan Pendapat di Timor Timur tetap berlaku sampai dengan terlaksananya ketentuan dalam Pasal 5 dan Pasal 6 Ketetapan Majelis Permusyawaratan Rakyat
Republik Indonesia Nomor VMPR/1999.

(c) Tap. MPR/S yang tetap berlaku sampai dengan terbentuknya pemerintahan hasil Pemilu 2004.

(d) Tap. MPR/S yang tetap berlaku sampai dengan terbentuknya undang-undang.

(e) Tap. MPR/S tentang Peraturan Tata Tertib MPR dinyatakan masih berlaku sampai ditetapkannya Peraturan Tata Tertib yang baru oleh MPR-RI hasil Pemilu 2004.

Sebagai produk legislatif yang dilahirkan oleh sebuah lembaga negara yang tidak secara tegas ditugasi oleh undang-undang dasar, ketetapan MPR dalam kenyataannya harus menghadapi suatu peninjauan kembali, suatu "review". Jika kita melihat kepada hasil peninjauan terhadap materi dan status hukum ketetapan MPR di atas, nampak bahwa keberadaan ketetapan MPR setelah dilakukan peninjauan tersebut, masih harus ditinjau ülang untuk menentukan nasibnya di masa yang akan datang.

Dani kedua sistem hukum yang kita kenal, yaitu suatu "judicial review" dan "legislatif review", dengan mengkaitkan pada metode peninjauan terhadap Ketetapan MPR, maka jelas bahwa MPR telah memillh "legislatif review" untuk melakukan "review", yaitu suatu peninjauan kembali terhadap seluruh Ketetapan MPR yang pemah diterbitkan. Berdasarkan kepada hasil peninjauan tersebut, temyata masih ada beberapa Ketetapan MPRyang perlu ditinjau kembali yaitu Ketetapan MPR yang dinyatakan tetap berlaku (Pasal2 Ketetapan MPR No. IMPR/2003). Untukmenyatakan status hukum Ketetapan MPR tersebut, tentunya perlu dikaitkan dengan keberadaan Ketetapan MPRdimasayang akan datang, apakah MPR sudah berketetapan untuk tidak menerbitkan Ketetapan MPR lagi. atau sebaliknya. Jika MPR sudah memutuskan 
tidak akan lagi mengeluarkan produk hukum bernama Ketetapan MPR, sebaiknya Pasal 2 Ketetapan MPR No. I/MPR/2003 tersebut perlu ditinjau ulang, apakah ketetapan-ketetapan MPR tersebut akan dimasukkan menjadi materi muatan undang-undang dasar (Konstitusi) atau dituangkan ke dalam undangundang. Dengan demikian untuk melakukan peninjauan terhadap Ketetapan-ketetapan MPR tersebut perlu diserahkan kepada lembaga lain bukan dilakukan oleh lembaga MPR sendiri karena MPR adalah lembaga politik. Sedangkan untuk menentukan status hukum suatu produk hukum adalah persoalan yuridis sehingga dalam hal ini yang lebih berwenang melakukan peninjauan terhadap Ketetapan MPR adalah Mahkamah Konstitusi.

\section{Kedudukan Ketetapan MPR/S dalam Hirarkie Peraturan Perundang undangan}

Dasar hukum mengenai Ketetapan MPR/ $S$ dalam UUD 1945 memang tidak diatur secara jelas dan tegas seperti halnya undangundang, peraturan pemerintah pengganti undang-undang, dan peraturan pemerintah. Walapun demikian, kita dapat menemukan dasar hukum itu melalui penafsiran sejumlah pasal yang ada dalam UUD 1945. Adapun dasar hukum Ketetapan MPR dapat kita temukan dalam ketentuan-ketentuan UUD 1945 (Sebelum Perubahan) yaitu:22 Pertama, Pasal 2 ayat (3): "Segala Putusan Majelis Permusyawaratan Rakyat ditetapkan dengan suara yang terbanyak". Kedua, Pasal 3 "Majelis Permusyawaratan Rakyat menetapkan
Undang-Undang Dasar dan Garis-garis Besar daripada Haluan Negara". Ketiga, Pasal 6 ayat (2): "Presiden dan Wakil Presiden dipilih oleh Majelis Permusyawaratan Rakyat dengan suara terbanyak".

Negara Indonesia menganut sistem demokrasi sebagaimana tercantum dalam alinea keempat Pembukaan UUD 1945 dan Pasal 1 ayat (2) UUD 1945 yang mengemukakan: “...Bahwa kemerdekaan kebangsaan Indonesia itu disusun dalam suatu Undang-Undang Dasar Negara Indonesia, yang terbentuk dalam suatu susunan negara Republik Indonesia yang berkedaulatan rakyat dengan berdasar kepada....". Pasal 1 ayat (2) UUD 1945 berbunyi, "Kedaulatan adalah di tangan rakyat, dan dilakukan sepenuhnya oleh Majelis Permusyawaratan Rakyat".

Pelaksanaan kedaulatan rakyat diwujudkan melalui tugas dan wewenang yang diberikan kepada MPR. Dari bunyi Pasal 2 ayat (3) yang menyatakan,"segaia putusan MPR ditetapkan dengan suara terbanyak", timbul pertanyaan, dalam bentuk peraturan apakah segala putusan MPR tersebut dituangkan? Pertanyaan tersebut juga berlaku terhadap putusan MPR yang berisi garis-garis besar haluan negara dan pengangkatan Presiden dan Wakil Presiden. Dalam bentuk peraturan apakah garis-garis besar haluan negara diatur, dan dalam bentuk apakah pengangkatan Presiden dan Wakil Presiden dituangkan?

Perlu diperhatikan bahwa, peraturan perundang-undangan hanya dapat dibentuk oleh lembaga-lembaga yang memperoleh kewenangan perundang-undangan

${ }^{22}$ Sri Soemantri. 1985. Ketetapan MPR(S) Sebagai Salah Satu Sumber Hukum Tata Negara. Cetakan Pertama. Remadja Karya. Bandung. HIm. 44. Lihat juga Bagir Manan. 2003. Teoridan Politik konstitusi. FH-UII Press. Yogyakarta.Hlm. 217. 
(wetgevingsbevoegdheid), yaitu kekuasaan untuk membentuk hukum (rechtsvorming). Mengenai itu tidak semua lembaga memperolehnya..$^{23}$ Suatu lembaga akan memperoleh kewenangan baik secara atribusi maupun delegasi.

Bagaimana dengan lembaga MPR? MPR tidak memperoleh kewenangan baik secara atribusi maupun delegasi untuk membentuk produk hukum bernama Ketetapan MPR. Tapi, kewenangan membentuknya diperoleh berdasarkan kepada wewenang (tugas) yang dimilikinya melalui UUD 1945 sebagaimana tersebut di atas. Sebenamya wajar bahwa suatu lembaga negara membuat aturan, terutama yang menjadi kompetensinya dan terkait dengan masalah yang berada dalam yurisdiksinya, MPR memiliki kompetensi itu. Masalahnya, apa bentuk pengaturan tersebut dan di mana letaknya dalam hirarkie hukum Indonesia? Selain berbentukUUD dan sesuatu yang disebut "garis-garis besar daripada haluan negara", UUD 1945 (Sebelum Perubahan) tidak memberi penjelasan lain tentang produk MPR.

Sebagai produk hukum MPR, Ketetapan Majelis Permusyawaratan Rakyat (Sementara) dipergunakan sebagai sumber hukum, sebenarnya masalah sumber hukum, khususnya tentang jenis-jenis peraturan perundang-undangan, tidak ditentukan secara sistematik dalam UUD 1945. Konstitusi ini hanya menyebut jenis-jenis peraturan perundang-undangan secara terbatas dengan tidak menegaskan hirarkienya. Maka berkembanglah keanekaragaman legislasi dalam praktik ketatanegaraan Indonesia, seperti penggunaan Makloemat, Penetapan Presiden dan lain-lain. Tetapi, pada dasarnya UUD 1945 menjadi "sumber yang pertama dan tertib hukum yang pertama". ${ }^{24}$

Menurut sejarah ketatanegaraan, sesaat setelah Proklamasi Kemerdekaan Negara Indonesia, tepatnya pada tanggal 18 Agustus 1945, mulailah berlaku Undang-Undang Dasar Republik Indonesia yang pertama. Setelah sempat menggunakan Konstitusi Republik Indonesia Serikat (1949) dan Undang-Undang Dasar Sementara (1950), UUD 1945 diberlakukan kembali pada tanggal 5 Juli 1959. Kemudian muncul sistematisasi dalam Surat Presiden RI tanggal 20 Agustus 1959, yang memunculkan berbagai produk hukum pemerintah (executive orders). Dalam Surat Presiden ini tata urutan peraturan perundang-undangan di Indonesia terdiri atas: (1) Undang-undang; (2) Peraturan Pemerintah; (3) Peraturan Pemerintah Pengganti Undang-undang, yang mencakup: (a) Penetapan Presiden untuk melaksanakan Dekrit Presiden tanggal 5 Juli 1959; (b)

\footnotetext{
${ }^{23}$ Maria Farida Indrati Soeprapto. 1998. IImu Perundang-undangan undangan Dasar-Dasar dan Pembentukannya. Kanisius. Yogyakarta. HIm. 54.

${ }^{24}$ Lihat Moh. Tolchah Mansoer. 1979. Sumber Hukum dan urutan Tertib Hukum menurut UndangUndang Dasar 1945. Bina Cipta.. Him. 8. Selanjutnya, Tolchah Mansoer mengemukakan bahwa pengertian sumber ialah, tempat asal pengambilan, landasan, segala hukum. Sedangkan pengertian tertib hukum ialah, tangga urutan, mana yang dipertamakan, dikeduakan, dan seterusnya. Sedangkan Harun Al Rasid mengatakan bahwa, Sumber tertib hukum sesuatu negara atau biasa sebagai sumber dari segala sumber hukum adalah pandangan hidup, kesadaran dan cita-cita hukum serta cita-cita moral yang meliputi suasana kejiwaan dan watak dari rakyat negara yang bersangkutan. Sumber dari segala sumber hukum di Indonesia dinamakan Pancasila. (Harun AI Rasid. 1996. Himpunan Peraturan Hukum Tata Negara. Edisi II. UI-Press. Jakarta. Hlm. 552).
} 
Peraturan Presiden didasarkan pada UUD 1945 Pasal 4 ayat (1) untuk melaksanakan Penetapan Presiden; (c) Peraturan Pemerintah untuk melaksanakan Peraturan Presiden; (d) Keputusan Presiden untuk melaksanakan pengangkatan; (4) Peraturan Menteri dan Putusan Menteri.

Terlihat bahwa UUD 1945 tidak dimasukkan sebagai peraturan perundangundangan, sehingga tidak ditempatkan pada urutan pertama hirarkie hukum dalam surat tersebut. Tapi tidak berarti bahwa, secara formal, konstitusi tidak digunakan sebagai sumber hukum. Meskipun demikian, praktik ketatanegaraan yang didominasi Presiden telah menghasilkan berbagai produk pemerintah (eksekutif) yang berlaku umum, bahkan mengintervensi lembaga legislatif dan yudikatif. Tampaknya terdapat inkoherensi dalam sumber dan hirarkie hukum, seperti berbagai Penetapan Presiden tentang pemberantasan kegiatan subversi. ${ }^{25}$

MPRS juga melakukan sistematisasi atas produk-produknya, yang terdiri atas: (1) Keputusan Musyawarah MPRS, yang menyangkut seluruh rakyat Indonesia serta mengandung arti dan maksud yang luas; (2) Keputusan Musyawarah Pimpinan MPRS, yaitu mengenai hal-hal tertentu dan terbatas. Tidak jelas seberapa terbatas jenis kedua produk MPRS ini, namun institusi pimpinan MPRS mendapatkan pengukuhan selama
Orde Baru karena berfungsi representasi dari lembaga, bahkan dirangkap dengan pimpinan DPR. Fungsi Pimpinan MPR kemudian dipisahkan pasca-Pemilu 1999, namun disatukan (dirangkap) dengan jabatan Badan Pekerja MPR.

Kemudian pada awal Orde Baru dilakukan sistematisasi sumber dan hirarkie hukum yang lebih komprehensif melalui Ketetapan No. XX/MPRS/1966. Sistematisasi ini diterapkan dalam kehidupan ketatanegaraan, meskipun muncul praktikpraktik yang berlebihan dan menunjukkan dominasi, bahkan otoritarianisme, pihak eksekutif yang pada akgirnya berkembang Keppres yang bersifat "pengaturan" (regulatif).

Dalam rangka pembaruan sistem peraturan perundang-undangan kita di era reformasi, MPR telah menetapkan Ketetapan No. III/MPR/2000 tentang Sumber Hukum dan Tata Urutan Peraturan Perundang-undangan. Namun, perumusan mengenai bentuk dan tata urutan ketujuh peraturan perundangundangan yang tercantum dalam Tap No. III/ MPR/2000, menurut beberapa ahli Hukum Tata Negara kurang sempurna dan mengandung kelemahan.

Sebagai bentuk hukum perundangundangan, Ketetapan MPR menempati urutan kedua setelah Undang-Undang Dasar 1945 dalam hirarkie tata urutan peraturan perundang-undangan. ${ }^{26}$ Penetapan tata urutan

\section{${ }^{25 F a j r u l ~ F a l a a k h . ~ M e n i n j a u ~ K e m b a l i ~ . . . ~ o p . ~ c i t . ~ H I m . ~ 39-40 . ~}$}

${ }^{20}$ Sebagai konsekuensi pengaturan mengenai tata urutan yang berjenjang, UUD harus ditempatkan sebagai suatu bentuk peraturan perundang-undangan. Kalau tidak, UUD tidak dapat dipakai sebagai penguji peraturan perundang-undangan tingkat lebih rendah. UUD harus ditegasḳan sebagai aturan hukum tertulis tertinggi dalam sistem tertib hukum yang berlaku. UUD menjadi hukum positif tertinggi, karena UUD membentukperaturan perundangundangan lainnya. Disamping itu, UUD merupakan sumber bagi keberadaan peraturan perundang-undangan atau aturan hukum pada umumnya. Lihat Bagir Manan. 2003. Teoridan ... op. cit. HIm. 227-228. 
tersebut, baik yang ada dalam Tap No. XXMPRS/ 1966 maupun dalam Tap No. III/MPR/2000 sebenamya tidak lain hanya dimaksudkan untuk mengurutkan tingkatan norma hukum perundangundangan, dimana norma yang di bawah tidak boleh bertentangan dengan norma di atasnya. $\mathrm{Hal}$ ini mengacu kepada teori stufentheori yang dikemukakan oleh Hans Kelsen.

Penyusunan tata urutan peraturan perundang-undangan tersebut tidak dimaksudkan untuk mengelompokkan norma-norma hukum perundang-undangan sebagaimana yang dimaksud oleh teori yang dikemukakan oleh Hans Nawiasky. Akan tetapi, ketika penyusunan tata urutan tersebut menggunakan istilah peraturan perundang-undangan (gesetz), penggunaan istilah tersebut mengundang kritik dari para teoritisi Hukum Tata Negara. Penggunaan istlah "peraturan Perundang-undangan" dalam hal ini dinilai tidak tepat karena dengan istilah peraturan perundang-undangan di dalam teori berarti menyangkut pengelompokan norma. Jika hal inj yang dimaksud, maka pencantuman Ketetapan MPR dan UUD 1945 dalam tata unutan tersebut menjadi tidak tepat karena berdasarkan pengelompokkan norma, Ketetapan MPR dan UUD 1945 bukan temasuk peraturan perundangundangan (gesetz), tetapi dimasukkan dalam kelompok staatsgrundgesetz. ${ }^{27}$

Selama ini, Ketetapan MPR berada dalam urutan kedua setelah UUD 1945 dalam tata urutan peraturan perundang-undangan dan menjadi sumber hukum bagi peraturan perundang-undangan yang berada di bawah Ketetapan MPR. Kemudian muncul pertanyaan, bagaimanakah kedudukan Ketetapan MPR dalam tata urutan perundangundangan setelah adanya perubahan UUD 1945? Berkaitan dengan hal tersebut Bagir Manan mengemukakan bahwa, kehadiran lebih kanjut Ketetapan MPR sebagai peraturan perundang-undangan tergantung pada keberadaan MPR. Kalau terjadi perubahan badan perwakilan menjadi sistem dua kamar, Ketetapan MPR dengan sendirinya hapus. Ketetapan MPR hanya terbatas pada wewenang MPR yang secara tegas disebutkan dalam UUD. MPR tidak boleh mengatur halhal yang tidak disebutkan dalam UUD. Kalau dari wewenang ini tidak ada yang dapat diatur sebagai peraturan perundang-undangan, maka Ketetapan MPR tidak akan ada dalam sistem peraturan perundang-undangan. ${ }^{28}$

Dengan demikian, MPR di masa yang akan datang tidak dapat lagi menerbitkan Ketetapan MPR yang bersifat mengatur (regeling), maka Ketetapan MPR yang selama ini berada dalam tata urutan peraturan perundang-undangan harus dikeluarkan. ${ }^{29}$ Kendati demikian, MPR masih mempunyai wewenang untuk menetapkan UUD 1945. Namun, jenis putusan yang harus ditetapkan bukan dalam bentuk Ketetapan MPR.

Dalam rangka penataan kembali sumber tertib hukum, dan tata urut peraturan perundang-undangan RI telah dikeluarkan UU

${ }^{27}$ Anji Sudjiman. Format Masalah Konstitusionalitas Ketetapan MPR Dalam Interpretasi UUD 1945. Buletin Legalitas. HIm. 33-34.

${ }^{29}$ Bagir Manan. Ibid. HIm. 219.

${ }^{29}$ Ketetapan MPR/S sudah dikeluarkan dari hirarkie peraturan perundang-undangan sebagaimana kita lihat pada Undang-Undang Nomor 10 Tahun 2004 tentang Pembentukan Peraturan Perundang-undangan (lihat tabel pada tulisan ini). 
No.10/2004 tentang Pembentukan Peraturan Perundang-undangan. Dalam undangundang tersebut tidak lagi menempatkan Ketetapan MPR/S sebagai sumber hukum dan tata urut peraturan perundang-undangan.

Dalam sistem hukum Indonesia, hirarkie peraturan perundang-undangan sejak tahun 1966-2004 dituangkan kedalam produk hukum sebagaimana digambarkan oleh tabel di bawah ini:

\begin{tabular}{|c|c|c|}
\hline $\begin{array}{l}\text { Ketetapan MPRS } \\
\text { No. XXMPRS/1966 }\end{array}$ & $\begin{array}{l}\text { Ketetapan MPR } \\
\text { No. IIUMPR/2000 } \\
\end{array}$ & $\begin{array}{l}\text { Undang-Undang } \\
\text { NO. } 10 \text { Tahun } 2004\end{array}$ \\
\hline $\begin{array}{l}\text { 1. UUD } 1945 \\
\text { 2. Ketelapan MPR } \\
\text { 3. UUUPespu } \\
\text { 4. PP } \\
\text { 5. Kepres } \\
\text { 6. Peraluran-pezaluran } \\
\text { pelaksanaan lainnya: } \\
\text { - Peraluran Menteri } \\
\text { - Instruksi Menteri }\end{array}$ & $\begin{array}{l}\text { 1. UUD } 1945 \\
\text { 2. Kelolapan MPR } \\
\text { 3. Undang-undand } \\
\text { 4. Perpu } \\
\text { 5. P e r a I u t a n } \\
\text { Pemerintah }\end{array}$ & $\begin{array}{l}\text { 1. UUD } 1945 \\
\text { 2.UU/Perpu } \\
\text { 3. Peraluran Pemerintah } \\
\text { 4. Peraluran Presiden } \\
\text { 5. Peraluran Daerah } \\
\text { - Perda Provinsidbuat } \\
\text { oleh DPRO dengan } \\
\text { Gubernur } \\
\text { - Perda Kab/Kola } \\
\text { dibual oleh DPRD } \\
\text { Kab/Kota bersama } \\
\text { Bupatinsalikota } \\
\text { - Peraluran Desal } \\
\text { peraluran yang } \\
\text { setingkat, dibual oleh } \\
\text { BPD alau nama } \\
\text { lainnya bersama } \\
\text { Kepala Desa alau } \\
\text { nama lainnya }\end{array}$ \\
\hline
\end{tabular}

\section{Status Hukum Ketetapan MPR/S di Masa Yang Akan Datang}

Setelah pelaksanaan Pemilu tahun 2004, penyelenggaraan Negara Republik Indonesia mengalami perubahan yang mendasar. Hal tersebut terlihat dalam pelaksanaan fungsi dan wewenang dari berbagai lembaga negara dan lembaga pemerintahan yang dilaksanakan sesuai dengan Perubahan UUD 1945.

Status hukum Ketetapan MPR setelah Pemilu Tahun 2004 sangat erat kaitannya dengan materi muatan yang terkandung dalam setiap Ketetapan MPR. Selain itu status hukum Ketetapan MPR berhubungan pula dengan sifat aturan hukum yang dirumuskan di dalamnya.

Kemudian timbul pertanyaan, bagaimanakah status hukum Ketetapan MPR pada masa pemerintahan transisi? ${ }^{30}$ Pada dasarnya, keinginan MPR untuk tidak menerbitkan Ketetapan MPR belum dinyatakan secara tegas. Keberadaan Ketetapan MPR/S di masa yang akan datang pun masih menimbulkan kontroversi, sebagian pihak menginginkan bahwa ketetapan MPR tetap diperlukan dan menjadi sumber hukum dalam tata urutan peraturan perundang-undangan. Dalam hal ini, Jimly Asshiddiqie mengatakan bahwa di masa mendatang Ketetapan MPR/S tidak dapat dipertahankan lagi, karena perubahan ketatanegaraan setelah Perubahan Keempat UUD 1945. Di masa depan MPR tidak lagi berwenang mengeluarkàn produk peraturan selain UUD dan Perubahan Undang-Undang Dasar. Di bawah UUD hanya ada undang-undang dan peraturan-peraturan yang lebih rendah. ${ }^{31}$

Hal senada juga dikemukakan oleh Mahfud MD, hanya saja, untuk masa transisi

${ }^{31} \mathrm{Jimly}$ Asshiddiqie. Struktur Ketatanegaraan Indonesia ... op. cit. HIm. 30.

${ }^{30}$ Transisi adalah peralihan dari keadaan (tempat, tindakan dan sebagainya) kepada yang lain. Lihat Kamus Besar Bahasa Indonesia. 1995. Edisi kedua, Cetakan Keempat. Departemen Pendidikan dan Kebudayaan. Balai Pustaka. Jakarta. Transisi juga didefinisikan sebagai titik awal atau interval (selang waktu) antara rezim otoritarian dengan rezim demokratis. Transisi itu dimulai dari keruntuhan rezim otoritarian lama yang kemudian diikuti atau berakhir dengan pengesahan (instalasi) lembaga-lembaga politik dan aturan politik baru di bawah payung demokrasi. Sutoro Eko. 2003. Transisi Demokrasi Indonesia Runtuhnya Rezim Orde Baru. APMD Press Yogyakarta. HIm. 12. Masa transisi berakhir hingga Pemilu tahun 2004. Kompas. 12 Agustus 2002. Bandingkan dengan A.S.S. Tambunan. 2002. Politik Hukum ... op. cit. Hlm. 145. 
Mahfud MD setuju jika keberadaan Ketetapan MPR/S tetap dipertahankan agar tidak menyebabkan terjadinya kekosongan hukum yang menimbulkan ketidakpastian hukum. Pernyataan tersebut adalah benar karena fenomena biasa yang muncul pada masa transisi adalah gejolak eforia politik masyarakat, yang nyaris tidak terkendali karena menemukan pintu kebebasan setelah sekian lama terkunci di dalam penjara kediktatoran rezim otoriter. Dalam kondisi demikian akan mudah menimbulkan anomalianomali hukum, yaitu tatanan hukum lama sudah tidak sesuai dengan perkembangan tuntutan perubahan, sedangkan sebaliknya tatanan hukum baru belum sepenuhnya terbentuk secara kokoh. Apalagi konfigurasi hukum yang tidak demokratis selama Orde Banu itulah yang kita warisi di masa pemerintahan transisi saat ini. ${ }^{32}$ Demikian juga hasil penelitian beberapa negara yang dirangkum oleh Guillermo O'Donnel dan Phillippe C. Schmitter dalam bukunya "transition from Authoritarian Rule", masa peralihan ini adalah masa yang sarat dengan ketidakpastian dan multi kemungkinan, sehingga menuju era "entah ke manan..33

Dalam kaitannya dengan hal di atas, di dalam masa transisi ini pun, sesuai hasil peninjauan terhadap materi dan status hukum Ketetapan MPR/S dalam Sidang Tahunan MPR 2003, yang akan menentukan status hukum Ketetapan MPR/S di masa mendatang belum juga tuntas dan masih menyisakan beberapa persoalan. Contohnya, pertama,
MPR belum menetapkan secara tegas bentuk hukum apa yang akan digunakan untuk mewadahi produk hukum sesuai dengan perubahan kewenangan yang dimilikinya: Kedua, adanya 3 (tiga) Ketetapan MPR/S yang masih dipertahankan, yaitu Ketetapan MPR/S No XXVIMPRS/1966, Ketetapan MPR No. XVI/ MPR/1998, dan Ketetapan MPR No. V/MPR/ 1999, yang kesemuanya merupakan Ketetapan MPR/S yang bersifat regeling (mengatur). Di sini muncul pertanyaan, bagaimana status hukum ketiga Ketetapan MPR/S tersebut apabila sudah tidak lagi ditempatkan dalam tata urutan peraturan perundang-undangan?

Uraian berikut ini dapat dijadikan alternatif untuk memberikan penyelesaian mengenai ketiga status hukum Ketetapan MPR/S tersebut. Pertama, terhadap Ketetapan MPRS No. XXVI MPRS/1966. ${ }^{34}$ Di level undang-undang, UU No. 12/2003 tentang Pemilu Anggota DPR, DPD, dan DPRD Pasal 60 huruf g yang substansinya berkaitan dengan Ketetapan MPRS tersebut telah dilakukan permohonan judicial review ke Mahkamah Konstitusi. Melalui putusannya, MK mengabulkan tuntutan pemohon perkara pengujian UU No. 12/2003, dan menyatakan Pasal 60 huruf g UU No. 12/2003 tersebut bertentangan dengan UUD 1945 serta tidak mempunyai kekuatan hukum mengikat. Bagaimana dengan Ketetapan MPRS No. XXV/MPRS/1966, apakah dengan adanya keputusan MK seperti di atas secara otomatis ketetapan tersebut gugur?

\footnotetext{
32Untuk iebih memahami masalah tersebut lihat bukunya Mahfud MD. 1998. Politik Hukum Di Indonesia. LP3ES kerjasama dengan UII Press. Yogyakarta.

${ }^{33}$ Lihat Agustin Teras Narang. 2003. Reformasi Hukum Pertanggungjawaban Seorang Wakil Rakyat. Pustaka Sinar Harapan. Jakarta. Him. 113.

${ }^{34 K e t e t a p a n ~ M P R S ~ t e r s e b u t ~ m e r u p a k a n ~ s a l a h ~ s a t u ~ y a n g ~ d i u s u l k a n ~ u n t u k ~ s e g e r a ~ d i c a b u t . ~}$
} 
Dari sisi kelanjutan putusan MK, ada dua pendapat yang berbeda. ${ }^{35}$ Pertama, keputusan MK ini, secara praktik ketatanegaraan dapat menjadi preseden dan dapat dianggap applied terhadap aturan-aturan yang sejenis. Kedua, pendapat yang menyatakan semua perundang-undangan yang dinilai diskriminatif mesti diuji materi satu per satu.

Untuk menyikapi kedua pendapat tersebut, sebagai alternatif penyelesaian sebaiknya materi Ketetapan MPRS No. XXV/ MPRS/1966 dimasukkan kedalam undangundang (Partai Politik) misalnya dengan rumusan:"Dilarang mendirikan partai komunis di Indonesia", atau "mendirikan partai yang berasaskan komunis". Sedangkan materi yang mengatur tentang larangan menyebarkan ajaran/paham Komunisme/MarxismeLeninisme perlu dicari bentuk peraturan perundang-undangan yang tepat.

Kedua, terhadap Ketetapan MPR No. XVI/ MPR/1998 tentang Politik Ekonomi Dalam Rangka Demokrasi Ekonomi. Ketetapan MPR tersebut yang mengandung beberapa amanat telah diatur dan dilaksanakan dengan berbagai peraturan perundang-undangan seperti UU tentang koperasi, perbankan, Bank Indonesia, dan tentang pinjaman luar negeri. Contohnya UU No. 23 Tahun 1999 tentang Bank Indonesia (diganti dengan UU No. 3 Tahun 2004 tentang Perubahan UU No. 23 tahun 1999), yang mengatur tentang bank sentral yang mandiri, bebas campur tangan pemerintah dan pihak luar hal yang seperti diamanatkan oleh Pasal 9 Ketetapan MPR No. $\mathrm{XVI/MPR/1998}$ yang menyebutkan: "Dalam rangka pengelolaan ekonomi keuangan nasional yang sehat. Bank Indonesia sebagai Bank Sentral harus mandiri, bebas dari campur tangan pemerintah dan pihak luar lainnya dan kinerjanya dapat diawasi dan dipertanggungjawabkan".

Ketentuan dalam pasal-pasal Ketetapan MPR ini mengatur secara garis besar tentang kebijaksanaan dalam politik dan ekonomi, disarankan untuk dibiarkan karena jika undang-undangnya telah ada maka, keberlakuan Ketetapan ini akan selesai dan materi dalam Ketetapan MPR ini diatur lebih lanjut dalam berbagai undang-undang sebagai pelaksanaan lebih lanjut.

Ketiga, mengenai Ketetapan MPR No. VI MPR/1999 tentang Penentuan Pendapat di Timor Timur. Secara umum Ketetapan ini berisi sikap MPR terhadap hasil penentuan pendapat yang dilakukan di Timor Timur. Terhadap materi yang terkandung dalam ketetapan ini ada beberapa hal yang perlu mendapat perhatian.

Dalam konsideran 'menimbang' MPR dalam Sidang Umum bulan Oktober 1999 menyatakan bahwa MPR menghargai hasil penentuan pendapat di Timor Timur dengan tidak mengesampingkan kenyataan bahwa persetujuan New York telah dilakukan oleh pemerintah tanpa meminta persetujuan DPR (konsideran 'menimbang', huruf f ). Pernyataan ini mengandung arti bahwa, (1) MPR menilai langkah-langkah Presiden ketika itu (Prof. Dr. Ir. B.J. Habibie) dalam penyelesaian kasus di Timor Timur memiliki masalah konstitusional yaitu mengenai prosedur demokrasi yang harus dilakukan oleh pemerintah tanpa meminta persetujuan DPR, padahal

${ }^{35}$ Todung Mulya Lubis. Putusan Mahkamah Konstitusi Perkara No. 011-017/PUU-1/2003 Dari Perspektif Hukum HakAsasi Manusia Intemasional. Dalam Jumal Konstitusi. Volume 1 Nomor 1 Juli 3004. Hlm. 25 
persetujuan tersebut yang menjadi dasar dilaksanakannya penentuan pendapat di Timor Timur hasilnya adalah berpisahnya Timor Timur dari Republik Indonesia. (2) MPR menghargai hasil penentuan pendapat yang telah dilakukan di Timor Timur. Artinya, betapapun telah terjadi permasalahan prosedur demokrasi yang dilakukan oleh pemerintah namun secara substansial hasil penentuan pendapat di Timor Timur diakui oleh MPR sebagai sebuah kenyataan. MPR membuktikan pengakuannya tersebut dengan mencabut Ketetapan MPR No. VI/MPR/1978 tentang Pengukuhan Penyatuan Wilayah Timor Timur ke dalam Negara Kesatuan Republik Indonesia. Materi Pasal 1 sampai dengan 4 dalam ketetapan ini bersifat einmahlig (sekali selesai). Terhadap pasal-pasal tersebut tidak perlu diambil tindakan apapun dalam kaitan peninjauan Ketetapan MPR karena sifatnya einmahlig.

Sementara, pada Pasal 5 diuraikan perintah MPR kepada Presiden Republik Indonesia untuk melaksanakan langkah-langkah setelah dilakukannya penentuan pendapat di Timor Timur untuk:

1. Melindungi warga Timor Timur dari akibat yang timbul karena pelaksanaan penentuan pendapat.

2. Mengambil langkah-langkah hukum tentang status kewarganegaraan warga Timor Timur yang tetap setia kepada Negara Kesatuan Republik Indonesia.

3. Bersama DPR mengambil langkah-langkah berkenaan dengan UU No. 7 Tahun 1976 tentang Pengesahan Penyatuan Timor Timur ke dalam NKRI sebagai tindak lanjut persetujuan New York 5 Mei. 1999.

Secara realitas hal-hal yang diperintah kepada Presiden dalam Pasal 5 ini belum selesai dilaksanakan oleh Presiden. Terutama tindakan hukum tentang status kewarganegaraan warga Timor Timur yang tetap setia kepada NKRI dan masalah UU No. 7 Tahun 1976 yang hanus diambil langkah-langkah dibidang perundangundangan mengingat isinya sudah tidak relevan.

Ketetapan MPR ini masuk kategori akan berakhir dengan sendirinya namun harus digarisbawahi, bahwa ketetapan ini akan berakhir dengan catatan:

1. Penyelesaian pengaturan masalah status kewarganegaraan, untuk warganegara Indonesia yang berada di Timor Timur maupun untuk warganegara Timor Timur yang berada di Indonesia.

2. Melakukan perubahan atas segala peraturan perundang-undangan yang masih mencantumkan Timor Timur sebagai salah satu propinsi Republik Indonesia contoh Pasal 118 UU No. 22 Tahun 1999, yang berbunyi:

a) Propinsi Daerah Tingkat I Timor Timur diberikan otonomi khusus dalam kerangka NKRI, kecuali ditetapkan lain oleh peraturan perundang-undangan.

b) Pengaturan

mengenai penyelenggaraan otonomi khusus, sebagaimana dimaksud pada ayat (1), ditetapkan dengan undang-undang.

UUD1945 tidak mencantumkan daerah batasan wilayahnya. Hal ini mungkin dengan pertimbangan, karena batas-batas wilayah suatu negara di kemudian hari akan mengalami perkembangan, untuk mengatasinya diperlukan traktat-traktat intemasional, sehingga tidak perlu selalu mengubah undang-undang dasar. ${ }^{36}$

${ }^{36}$ Moh. Tolchah Mansoer. 1979. Sumber Hukum ... op. cit. Hilm. 4 
Terkait dengan hal tersebut, dengan masuknya Timor Timur luas wilayah Republik Indonesia menjadi bertambah namun, untuk saat ini kenyataan menjadi berbeda, ketika Timor Timur menyatakan keluar dari Negara Kesatuan Republik Indonesia otomatis luas wilayah Negara Republik Indonesia berkurang. Materi Ketetapan MPR No. V/MPR/ 1999 dapat dikatakan menyangkut luas wilayah sehingga tidak dapat dituangkan ke dalam undang-undang dasar. Untuk itu, ketetapan tersebut disarankan masuk menjadi materi muatan undang-undang.

Dari uraian di atas nampak bahwa, keberadaan Ketetapan MPR/S setelah perubahan UUD 1945 masih menimbulkan persoalan, status hukumnya tidak jelas, dikatakan masih ada ketetapan tersebut tidak "bermakna" namun, jika tidak dipergunakan lagi dalam kenyataannya masih ada dan dinyatakan masih berlaku. Untuk itu, upaya menyikapi ketidakjelasan status Ketetapan MPR/S seharusnya segera dibentuk peraturan perundang-undangan guna menampung persoalan-persoalan yang berkaitan dengan masalah tersebut

Pendapat yang mengatakan bahwa, Ketetapan MPR yang keberadaannya berdasarkan konvensi hanya dapat ditiadakan jika berkembang konvensi yang sebaliknya. Kemungkinan kearah itu sangat mungkin terjadi mengingat kewenangan MPR yang menjadi sebab lahirnya konvensi tersebut sudah tidak lagi dimilikinya. Seperti tercantum pada Pasal 3 UUD 1945, yang berbunyi: "Majelis Permusyawaratan Rakyat menetapkan undangundang dasar dan garis-garis besar daripada haluan negara". Karena menetapkan maka bentuk hukum yang digunakan adalah 'Ketetapan'. Memang MPR masih mempunyai wewenang menetapkan UUD 1945, tapi putusan yang digunakan bukan bentuk ketetapan MPR melainkan "Perubahan Undang-Undang Dasar" tanpa menggunakan nomor putusan Majelis. ${ }^{37}$ Atas dasar itu, tidak ada lagi argumentasi yang dapat dijadikan alasan untuk mempertahankan dasar hukum 'Ketetapan MPR'.

Sebagai aturan hukum yang melaksanakaan ketentuan dalam Undang-Undang Dasar 1945, yang berisi aturan hukum untuk menjalankan ketentuan dalam Pasal 3 ayat (2) dan ayat (3), serta Pasal 8 ayat (2), dan ayat (3), maka Ketetapan MPR yang dibentuk setelah Pemilu tahun 2004, merupakan Ketetapan MPR yang bersifat individual, konkrit, dan final (einmalig). Sedangkan Ketetapan MPR yang dibentuk untuk mengatur keanggotaan dan tata kerja MPR, yang biasanya disebut dengan Peraturan Tata Tertib merupakan suatu pengaturan yang bersifat mengatur ke dalam (intern regelingen).

Dengan demikian, status hukum Ketetapan MPR yang dibentuk setelah Pemilu tahun 2004 adalah tetap merupakan aturan hukum yang hanya mengikat secara individual, konkrit, dan final; terhadap Presiden dan/atau Wakil Presiden. Selain itu juga Ketetapan MPR yang merupakan aturan hukum yang mengikat ke dalam (intern regelingan). Setelah Pemilu tahun 2004, MPR tidak dapat lagi membentuk Ketetapan MPR yang bersifat mengatur sepert layaknya suatu peraturan perundangundangan (wettelijke regelingen) ataupun peraturan kebijakan (beleidsregels).

Namun, untuk menghindari kerancuan

${ }^{37}$ Pasal 90 Ketetapan MPR No. II/MPR/1999 tentang Peraturan Tata Tertib MPR. 
pemahaman terhadap Ketetapan MPR, sebaiknya produk hukum yang dikeluarkan oleh MPR di masa yang akan datang atau setelah Pemilu tahun 2004, menggunakan 'nomenklatur' lain selain 'Ketetapan MPR', karena ke depan MPR tidak lagi mengeluarkan produk hukum yang bersifat mengatur (regeling) yang berisi aturan hukum (rege/s) kecuali mengatur ke dalam (intern regelingen), dan hanya mengeluarkan produk hukum yang bersifat konkrit, individual dan final, maka sebaiknya digunakan nomenklatur atau istilah 'Keputusan'(MPR) saja.

\section{Simpulan}

Berdasarkan uraian di atas, dapat disimpulkan keberadaan Ketetapan MPR setelah Perubahan Undang-Undang Dasar 1945 masih menimbulkan persoalan, karena MPR belum mengambil keputusan secara tegas yang bersifat menyeluruh terhadap produk hukum ketetapan MPR yang masih dinyatakan berlaku.

Alternatif penyelesaian terhadap status hukum ketetapan MPR/S yang masih berlaku di masa yang akan datang, ialah perlu adanya suatu sikap tegas yang intinya adalah: substansi penting yang ada/termuat dalam Ketetapan MPRS dan Ketetapan MPR dituangkan ke dalam bentuk peraturan perundang-undangan, paling tidak yang setingkat undang-undang.

\section{Daftar Pustaka}

A.S.S. Tambunan. 1991. MPR Perkembangan dan Pertumbuhannya Suatu Pengamatan dan Analisis, Cetakan
Pertama. Muliasari. Jakarta.

. 2002. Politik Hukum Berdasarkan UUD 1945. Puporis Publisher. Jakarta

Azhary. 1995. Negara Hukum Indonesia, Analisis Yuridis Normatif Tentang Unsur-unsurnya. UI Press. Jakarta.

Bagir Manan 2003 "DPR, DPD dan MPR dalam UUD 1945 Baru', FH UII Press. Cet. 1. Yogyakarta.

Bagir Manan. 1992. Dasar-Dasar PerundangUndangan Indonesia. Ind-Hill. CO. Jakarta.

. 2003. Teori dan Politik konstitusi. FHUII Press. Yogyakarta.

Dahlan Thaib. 2000. Kedaulatan Rakyat Negara Hukum dan Konstitusi. Cetakan Kedua. Liberty. Yogyakarta

Frans Magnis Suseno. 1989. Etika Politik. Gramedia Pustaka Utama. Jakarta.

Ismail Suny. 1987. Mekanisme Demokrasi Pancasila. Aksara Baru. Jakarta.

K.C. Wheare. 2003. Modern Constitutions. Penerjemah Muhammad Hardani. Konstitusi-Konstitusi Modern. Cetakan Pertama. Pustaka Eureka. Surabaya.

Maria Farida Indrati Soeprapto. 1998. IImu Perundang-undangan Dasar-Dasar dan Pembentukannya. Kanisius. Yogyakarta

Moh. Mahfud MD. 1993. Demokrasi dan Konstitusi di Indonesia. Liberty. Yogyakarta.

Moh. Kusnardi dan Harmaily Ibrahim. 1980. Pengantar Tata Hukum Indonesia. Pusat Studi HTN dan Sinar Bakti. Jakarta. 
Sri Soemantri. 1985. Ketetapan MPR(S) Sebagai Salah Satu Sumber Hukum Tata. Negara. Cetakan Pertama. Remadja Karya. Bandung. - 1987. Prosedur dan Sistem Perubahan Konstitusi. Cetakan Keempat. Alumni. Bandung

Undang-Undang Dasar dan Ketetapan Majelis Permusyawaratan Rakyat Sebagai Produk Majelis Permusyawaratan Rakyat. Pidato Pengukuhan Jabatan Guru Besar Tetap Dalam Mata Kuliah IImu Hukum Tata Negara pada FH Universitas Padjajaran, Sabtu, 21 Februari 1987

MPR RI. 2003. Panduan Dalam Memasyarakatkan Undang-Undang Dasar Negara Republik Indonesia Tahun 1945, Latar Belakang, Proses dan Hasil Perubahan Undang-Undang Dasar Negara Republik Indonesia Tahun 1945. Sekretariat Jenderal MPR RI.Jakarta.

Undang-Undang Dasar 1945 Sebelum dan Setelah Perubahan

Ketetapan MPR/S
Kompas, 1 Agustus 2003.

Jurnal Hukum. No. 6 Vol. 3 Tahun 1996

Laporan Akhir Kajian tentang "Peninjauan terhadap Materi dan Status Hukum Ketetapan MPRS dan MPR Tahun 1960-2002". Kerjasama Setjen MPR$\mathrm{Rl}$ dengan UGM. Yogyakarta. 2002.

Jimly Asshiddiqie. Struktur Ketatanegaraan Indonesia setelah Perubahan Keempat UUD Tahun 1945. Makalah disampaikan pada: Seminar Pembangunan Hukum Nasional VIII Tema "Penegakan Hukum Dalam Era Pembangunan Berkelanjutan" Diselenggarakan Oleh Badan Pembinaan Hukum Nasional Departemen Kehakiman dan Hak Asasi Manusia RI. Denpasar, 14 - 18 Juli 2003.

Laporan Penelitian "Tinjauan Terhadap Materi dan Status Hukum Ketetapan MPR/S Al Tahun 1960-2002". Oleh Tim Pusat Stuadi Hukum Tata Negara Fakultas Hukum Universitas Indonesia. Kerjasama dengan Sekretariat Jenderal MPR-RI Jakarta. Mei 2003." 